\title{
Innovating During Tough Times: Lessons from the Great Composers
}

\author{
Terry Leap ${ }^{1} \&$ David W. Williams ${ }^{1}$ \\ ${ }^{1}$ Department of Management, Haslam College of Business, The University of Tennessee, Knoxville, TN, USA \\ Correspondence: David W. Williams, Department of Management, Haslam College of Business, The University \\ of Tennessee, 416 Stokely Management Center, 916 Volunteer Boulevard, Knoxville, Tennessee 37996, USA. \\ Tel: 1-865-974-1666. E-mail: dww@utk.edu
}

Received: November 6, 2014

Accepted: November 21, 2014

Online Published: December 25, 2014

doi:10.5539/ibr.v8n1p191

URL: http://dx.doi.org/10.5539/ibr.v8n1p191

\begin{abstract}
Today's economic environment appears rather inhospitable for innovation - high uncertainty, scarce financial resources, and intensifying competition - each serves to make entrepreneurs' and managers' efforts to innovate less likely to succeed. To assist entrepreneurs and managers today, we turn the clock back to the great classical composers - from whom we find timeless advice about how to succeed in difficult circumstances. As world-class musicians, it is obvious that the great classical composers were supreme innovators. But they often performed their work under trying conditions in tumultuous times. Early composers had to be musically creative as well as adept at finding resources to develop and market their work. They faced political suppression and religious discrimination, weak government protection of their intellectual property, and often faced physical dangers in addition to economic challenges that make today's economic downturn look mild. Drawing from the collective wisdom of these great innovators, we offer to today's managers and entrepreneurs a way forward for innovating in tough times.
\end{abstract}

Keywords: composers, creativity, entrepreneurship, history, innovation

\section{Introduction}

\author{
"There's nothing remarkable about it. All one has to do is hit the right keys at the right time \\ and the instrument plays itself." -- Johann Sebastian Bach \\ "Give me a laundry list, and I'll set it to music." -- Gioacchino Antonio Rossini
}

The great composers of the $18^{\text {th }}, 19^{\text {th }}$, and early $20^{\text {th }}$ centuries developed a rich music tradition that continues to bring enjoyment to listeners worldwide. In addition to creating brilliant concertos, symphonies, and operas, these musicians were superb entrepreneurs. Although their musical accomplishments have eclipsed their entrepreneurial achievements, the great composers worked in ways that innovators today should appreciate. Here is a distillation of their entrepreneurial wisdom.

\section{Creative Workaholics Can Generate a Lot from a Little}

By today's standards, the great composers were incorrigible workaholics. They had to be both musically creative and adept at using bricolage to make do with whatever resources were at hand. Composers from the pre-electronic age had no way to distribute recordings of their music. If they wanted something done, they usually had to do it themselves without the support of assistants, a publicity machine, or reliable financial backing. Their work kept them moving from one major European city to another, carrying trunk loads of music over rough roads infested with highwaymen. And, as if these thieves were not enough, the great composers had to protect themselves from competitors who plagiarized their work.

The great composers fine-tuned and polished their work in ways that sometimes created the impression that they were monomaniacal or obsessive-compulsive. They worked late into the night, often at an exhausting pace, producing copious high-quality works. Most of the great composers ignored standard time tables; they ate and slept at unusual hours and gave little deference to deadlines.

High Baroque-era composer George Frideric Handel produced more than 2,000 arias. Robert Schumann, in 1840 alone, composed 147 songs. Classical composer Franz Joseph Haydn typically worked from 6:30 a.m. to 11:30 p.m. daily, and his 68 string quartets are still regarded as exemplars of the Classical era (i.e., compositions from the Baroque [1600-1750], Classical [1750-1825], Romantic [1825-1910], and early Modern eras [early 20th 
century]). Mozart would rise at 6:00 a.m., compose for several hours, and then give music lessons. After a late lunch, he would return to his composing around 5:00 p.m. and often work into the early morning hours, sleeping only two to six hours a night. In his short life (he died in late 1791 at age 35), Mozart produced hundreds of musical compositions, including nine major symphonies and 22 operas.

The great composers possessed no magic, and they did not compose masterpieces quickly or out of thin air. Their musical excellence was built on a foundation of creative thinking, painstaking writing and rewriting, polishing, and rehearsing. Johann Sebastian Bach's two-and-one-half hour St. Matthew's Passion is a grand illustration of meticulous work. Although the first page of the manuscript took a mere twenty seconds to perform, it had at least 450 notes written on 24 staves. Twenty pages later, the manuscript contained 800 notes encased in countless flats, sharps, naturals, rests, and words. That segment alone occupied about 22 seconds of the entire Passion (Steen, 2003).

Unless they were fortunate enough to have a major benefactor, many of the great composers had to put day-to-day living and searching for their next meal ahead of creativity. The great composers demonstrated that being successful sometimes required a "second" job. Mozart, for example, spent much of his day giving music lessons. Other composers worked at multiple jobs - cantor, teacher, business person - to support themselves and their families while still finding time to pursue their writing and performing. Pulitzer Prize winner Charles Ives, a composer of more recent vintage (late $19^{\text {th }}$ and early $20^{\text {th }}$ centuries), was an insurance executive and expert estate planner by day and a world-class composer by night. Ives spent his adult life working in the insurance industry, founding and managing his own company (Humanities Web, 2004). This lesson parallels the paths of today's entrepreneurs (Goodman, 2011).

\section{There Is a Fine Line between Innovation and Staleness}

Although hard work, resourcefulness, and persistence can produce excellence, stubbornness and resistance to change can cause one's work to go stale. Chopin provides a cautionary tale; he preferred the detail, delicacy, and refinement of the Pleyel piano rather than the sound of the more powerful grand piano, a strategy that kept him off the concert stage and away from more lucrative opportunities (Steen, 2003). He worked slowly and meticulously, never fully satisfied with a composition and never feeling that it was quite ready to send to the publishers. As a result, Chopin allowed his repertoire to languish and lose its appeal to musical audiences (Steen, 2003). Similarly, Mozart clung to a style of music that was viewed by critics and patrons as too difficult and complex, a criticism that hurt his reputation as a composer. Beethoven's career stagnated temporarily when he felt that he had "found" the musical formula for success and when, for a time, he failed to explore the new musical styles that were emerging in post-Napoleonic Europe.

\section{4. "Doesn't Work Well With Others" Might Be a Virtue, Not a Vice}

Business educators and consultants today emphasize the importance of leadership and teamwork. The networking and impression management skills that are an integral part of the current business world were of little concern to most of the great composers. In fact, they usually preferred to work alone - not a bad idea considering how dreadful their interpersonal skills could be. As children, these composers often regarded their musical instruments as surrogate friends. As adults, they were often disrespectful, even hateful, to the people around them.

At the pinnacle of their careers, Richard Wagner and Franz Liszt were cult figures, seemingly above reproach and scornful of critics (Greenberg, 2013a) (Note 1). Wagner, however, spent his twilight years living beyond his means and running from creditors. Liszt spent his last years estranged from his family and housed in a Roman monastery. Mozart, despite his prodigious talent, could be coarse and irreverent. Bach, like Beethoven, seemed to thrive on being out of step and defying authority. Brahms also had a churlish side that destroyed friendships and working relationships; he was kind and generous to working people, associates, and children while reserving a biting and malicious wit in artistic and aristocratic circles. His bad personality was accentuated by his slovenly appearance. Brahms was also a music historian's nightmare, defiantly destroying a great deal of his music as well as most of his lifetime correspondence. Both Frederic Chopin and Felix Mendelssohn made their way to the top of the musical world despite being high strung and contentious. Dmitri Shostakovich had a knack for making "his closest and most senior henchmen feel completely and permanently insecure" (Steen, 2003, p. 850).

But, at the other extreme, an inferiority complex may also spur creativity. Gnawing personal insecurities pushed some of the great composers into elevating their performance. Brahms, despite being rich and famous, felt that his music was inferior to the works of Bach, Mozart, and Beethoven. Seemingly paralyzed by the prospect of rejection, he took 15 years to complete his first symphony, and he burned his first twenty string quartets before allowing one to be published (Greenberg, 2013a). Gustav Mahler's isolated existence, romantic failures, and 
grieving found its way into his funeral marches. Tchaikovsky, after losing his mother when he was a teenager, developed fears over his turbulent romantic life. Rather than letting depression and self-loathing destroy him, he used his personal problems as motivation to intensify his efforts and to heighten his creativity.

\section{Good Ideas May Come from Unusual Places}

Modern-day management theorists talk about creativity as a precursor to innovation, often employing hackneyed, threadbare phrases such as "best practices," "leveraging functional capabilities," or "creating synergies." The great composers, while short on weasel words and jargon, often sought new ideas in unusual places. They developed strong links with the other arts, especially literature. But they were neither swayed by musical tradition, which could breed staleness, nor by musical fanaticism, which could breed carelessness.

Robert Schumann, who was both an aspiring poet and novelist, believed that the future of music depended on its fusion with literature and poetry. Both Richard Wagner and Hector Berlioz blended their symphonies and operas, respectively, with the arts. Berlioz was especially inspired by Goethe's Faust (Steen, 2013). Franz Liszt "brought to music unprecedented emotional and psychological impact that previously never existed" (DiSilvio, n.d.). Brahms's work epitomized the values of the German bourgeoisie, and he was influenced heavily by Hungarian folk music. Although he was a Romantic-era composer, Brahms used music from the great Baroque artists Bach and Handel, by then some 100 years in the past, to craft his Viennese orchestral work (Steen, 2003). Beethoven's contemporaries believed that music was based upon established rules and structures, mainly the sonata-allegro form. A major reason behind the anti-authoritarian Beethoven's success, of course, was his notorious disregard for standard conventions. When new ideas were in short supply, some composers reportedly lengthened, shortened, or re-arranged a theme. Others re-wrote the same music backwards, upside down, or both (Steen, 2003)!

\section{Everyone Loses Momentum, but the Great Ones Know How to Regain It}

Despite ranking high on something called "musical talent," the creativity of some great composers followed an uneven course. The work of the great composers can best be characterized as a form of punctuated equilibrium - periods of dormancy that were often followed by brilliant revitalization. The composers' key to enduring fame seemed to be developing one's talents at a very early age, receiving good mentorship, serving some form of apprenticeship, and refining and sharpening their skills to a fine edge.

Hayden's vocal talents, not his talent as a composer, were recognized in his youth. Once his youthful tenor voice gave way to adulthood, he avoided retreating into anonymity by developing his vast compositional talents. Robert Schumann, both a great composer and a great critic, took a nine-year hiatus from his profession before returning with a vengeance. When Handel's musical business declined, he rebounded by creating the oratorio, the most notable being The Messiah.

As artists and entrepreneurs, European composers faced harsh and even dangerous criticism. Parisian audiences often expressed their displeasure by pelting bad performers with rotten fruit. Franz Schubert was told by the Viennese publishing house, Artaria, "our public does not yet sufficiently and generally understand the peculiar, often ingenious, but perhaps now and then somewhat curious procedures of your mind's creations. Kindly therefore bear this in mind on sending me your manuscripts" (Steen, 2003, p. 227). Brahms spent four years working on his Piano Concerto in D minor only to have it savaged by critics in the late 1850s. At the same time, he had a falling out with the musical establishment over his public objections to the "progressive" school of music in Germany (Steen, 2003). Nevertheless, Brahms shunted aside these criticisms and made his name in Europe with the German Requiem that, according to Clara Schumann, was "a truly tremendous piece of art which moves the entire being in a way little else does" (Zebrowski, 2002).

\section{Dealing with Customers-Little Things Mean a Lot}

Because the great composers constantly promoted their music before live audiences, they understood the critical importance of face-to-face customer relations. Franz Liszt's concert tours, for example, took him over thousands of miles of rutted roads, mainly in mail carriages, as he journeyed to far flung places such as St. Petersburg, Gibraltar, Istanbul, and Lisbon. The great composers also did a marvelous job of communicating and staying abreast of developments in the European musical world, even in a time when word of mouth and truly snail-paced mail were the only modes of communication.

Once in the concert hall or theater, the great composers were mindful of their audience's needs. While directing the Vienna Opera, Gustav Mahler instituted several customer-friendly practices. He abolished the practice of "claques" in which singers bought and distributed blocks of tickets to form their personal cheering (or jeering) sections. As a courtesy to audiences, Mahler banned late-comers, regardless of their aristocratic status, from 
entering the opera hall. He also did away with providing complimentary tickets to critics, forcing them to buy their own. Other opera composers sold printed librettos to patrons along with a candle for easy reading in darkened theaters. Similarly, the Italian composers provided librettos with English translations.

\section{For Better or For Worse, Mentors Can Make a Big Difference}

The great composers learned that good mentors enhance creativity and bad ones stifle it. Johann Sebastian Bach had five sons who became highly-respected musicians, no doubt due to their inherited talents and strong family support. A young Beethoven worked for 12 years under the tutelage of Christian Neefe, who was both a mentor and a friend. Brahms got his big break when the famous violinist, Joseph Joachim, arranged for him to perform before King George V. Until early adulthood, Mozart was mentored by his father, Leopold (the proverbial "helicopter parent" by today's standards). Liszt's father, Adam, was an excellent organizer who knew how to promote a concert. Stravinsky came from a musical family. The fact that his father was a professional opera singer helped to fuel his intense ambition and to develop his musical talents.

Some musical mentors, however, wanted to live their lives through their protégés and they were quick to pull the financial plug when their pupils became obstinate or did not follow the mentor's preferred path. Hector Berlioz obtained a medical degree, his father wanted him to be a lawyer, and his mother warned him about becoming a musician. Obviously, he didn't listen. After his father cut off his allowance, Berlioz was forced to scrape by giving music lessons, writing articles, and singing in vaudeville acts. He subsided on leeks, vinegar, mustard, cheese, lard, and bread. The rare protein dish came from the occasional quail that he and his roommate trapped (Steen, 2003). Tchaikovsky's family tried to encourage him away from music and into "the more suitable" profession of civil servant. Robert Schumann's mother wanted her son to pursue a law career, and she encouraged him to attend lectures on this topic at the university in Heidelberg. When he insisted on a career in music she tried in vain to manipulate him through guilt trips and through threats of withdrawing financial support.

Mentors whose financial status and ego are not tied to a protégé's success are more likely to provide objective advice. Haydn, known affectionately by younger musicians as "Papa," was probably the greatest of musical mentors. He quickly spotted the talent of Mozart and developed a warm friendship with him as he did with many other young musicians (Note 2). Brahms probably would not have reached the pinnacle of the mid to late $19^{\text {th }}$ century musical world without the help of Robert and Clara Schumann. In turn, Brahms inspired younger composers like Gustav Mahler and Antonin Dvorak.

\section{Dealing Effectively With Personal Distractions Is a Must}

Many of the great composers had strong libidos, and their unorthodox love lives included a variety of trysts and betrayals. Dealing with a treacherous romance - the chase, the clandestine affair, and the rejection-failed to distract the great composers for any length of time. Brahms pushed on in spite of his love for the married Clara Schumann. Mozart suffered a painful rejection by singer Aloysia Weber, and Beethoven pursued a variety of unattainable women. Franz Liszt's mistress of four years, Marie d'Agoult, wrote Nelida, a best-selling but thinly-disguised novel intended to expose her affair with the famous composer.

Painful health problems, life-threatening illnesses, and the specter of death were also an ever-present concern. Beyond innate talent, many of the great composers had strong constitutions that compensated for their horrendous health habits. Some abused alcohol and others suffered the effects of tuberculosis, sexually transmitted diseases, poor nutrition, and sleep deprivation. For example, Nicolò Paganini, the virtuoso violinist who performed during the first half of the 19th century, was especially well known for his compulsive gambling and debauchery. He was thought to have sold his soul in exchange for his unparalleled skills, and it was rumored that Satan guided Paganini's fingers during his performances. Although Paganini could even bring the house down by playing the violin using a single string, his affliction with Ehlers-Danlos syndrome, a joint disease that gave him great flexibility, actually aided his masterful performances (Paganini Family, 2000).

Much has been said about Beethoven's hearing loss and the distress that it caused him. Beethoven had two four-year lulls in his career, between 1785 and 1789, and again between 1815 and 1819 (Note 3). His health problems, however, seemed to drive him harder as he vowed to "take fate by the throat" and "embrace the whole world" (Greenberg, 2013b). By the mid-1820s, he had pushed everything aside and began working tirelessly, composing five string quartets and the Grosse Fugue. During the twilight of his career, the nearly deaf Beethoven, fallen from public grace and battling mental health problems, composed his glorious Symphony no. 9, a work that eclipsed the time-honored classical forms.

Claude Debussy continued to immerse himself in his work despite suffering the pain of rectal cancer (Steen, 
2003). Soviet composer Dmitri Shostakovich and his family were shuttled from one place to another under the Stalin regime, being forced at one point during World War II to live for two years in a school library where they were surrounded by disease, illness, and death. Neglectful caretakers pushed the school-aged Haydn into the streets, forcing him to sing for his supper in the homes of nobility (Steen, 2003).

Losing a spouse, lover, or child was commonplace, especially in the $18^{\text {th }}$ century. Bach had 20 children, seven with his first wife and 13 with his second wife. Only nine of his children survived to adulthood, something that was surely a source of intense grief for him. Perhaps the monomania of the great composers enabled them to stay focused and to avoid straying too far from their work, no matter what the distraction.

\section{Governments Are, at Best, Indifferent to and, at Worst, a Thorn in the Side of Innovators}

Many of the great composers had to deal with intolerant regimes as well as religious and ethnic discrimination. The European governments of that era offered little support to musicians, preferring to regulate rather than to promote their work. For example, the governments of some European countries regulated the type of music that could be played in concert halls. Additionally, the revolutions that plagued Europe in 1848 also put many musicians out of business as did the economic recessions that curbed consumer spending. Jewish composers such as Mendelssohn and Mahler suffered from intense discrimination. Later musicians were confronted with the horrors of Stalin and Hitler; they walked on eggshells, carefully separating their public opinions from their private thoughts.

Then, as today, intellectual property protection problems hampered innovators' efforts. Plagiarism was a concern for most of the great composers. Copyright laws protected literary works, but it was not clear whether these laws also protected musical works. Because of the lack of copyright protection in the wake of the Bolshevik Revolution, Stravinsky received no royalty income after 1917 for performances of The Firebird. According to music historian Robert Greenberg: "Neither Haydn nor Mozart developed in a vacuum. In their apprenticeships, they copied, imitated, paraphrased, and stole from other composers, internalizing existing music so that they could go on to create new and original music of their own" (Greenberg, 2013c). So, composers had to stay one step ahead of the shysters who wanted to steal their works. To avoid the risk of piracy, Chopin had his works published simultaneously in France, Germany, and England (Steen, 2003). Another anti-pirating measure was for a composer to avoid printing music, instead selling only manuscript copies (Steen, 2003).

\section{Conclusion}

A world-wide cottage industry of entrepreneurial consultants developed during the latter part of the $20^{\text {th }}$ century. Paradoxically, some of the expert advice now given to innovators and entrepreneurs such as being a good leader, developing a clear and consistent message, and surrounding oneself with a competent team would have held little meaning for the likes of the "Killer Bees"-Bach, Brahms, and Beethoven. They were often an enigma, being eccentric, irascible, and introverted. Yet they created a cultural endowment that is still treasured.

The great composers were an exotic mixture of extreme talent, hustle, and tenacity. Like current-day innovators, the great composers prospered through the good times, but they were on top of their game during the bad times. They illustrate that creativity and innovation often require going against the grain, developing a thick skin, and deferring gratification. By looking back at the timeless lessons from these great composers, creative executives and entrepreneurs who savor a Bach piano sonata, a Mozart string quartet, or a Beethoven symphony might also savor the entrepreneurial wisdom of these musical masters.

\section{References}

DiSilvio, R. (n.d.). Liszt and modern music. The Franz Liszt Site. Retrieved from http://www.dvbooks.net/music/franzliszt.htm

Goodman, M. (2011, November 22). How to bootstrap your business. Entrepreneur. Retrieved from http://www.entrepreneur.com/article/220733

Greenberg, R. (2013a). Great masters: Brahms - His life and music [Recorded Lecture]. Chantilly, Virginia: The Teaching Company. Retrieved from http://www.thegreatcourses.com/tgc/courses/course_detail.aspx?cid=757

Greenberg, R. (2013b). Symphonies of Beethoven [Recorded Lecture]. Chantilly, Virginia: The Teaching Company. Retrieved from http://www.thegreatcourses.com/tgc/courses/course_detail.aspx?cid=730

Greenberg, R. (2013c). Great masters: Haydn—His life and music [Recorded Lecture]. Chantilly, Virginia: The Teaching Company. Retrieved from http://www.thegreatcourses.com/tgc/courses/course_detail.aspx?cid=751 
Humanities Web. (2004). Charles Ives biography. Retrieved from http://www.humanitiesweb.org/human.php?s=c\&p=c\&a=b\&ID=98

Paganini Family. (2000). Nicolò Paganini biography. Retrieved from http://www.paganini.com/nicolo/nicindex.htm

Steen, M. (2003). The lives and times of the great composers. London: Icon Books.

Zebrowski, A. (2002, August/September). Brahms' German requiem. Sunrise, 52. Retrieved from http://www.theosociety.org/pasadena/sunrise/51-01-2/ar-azeb.htm

\section{Notes}

Note 1. Brahms despised the tremendous influence that Liszt and Wagner had as arbiters of public taste, media, and morality. He and violinist Joseph Joachim drafted a manifesto clearly challenging the "Music of the Futurists" and exposing them as frauds. Although Brahms actually liked Wagner's music, he detested the cult that Liszt and Wagner had created.

Note 2. Haydn's attempts to do the same with Beethoven, however, were much more troubled.

Note 3. Musical historians view Beethoven's career as having three distinct stages: the Viennese period (1792-1802) in which he composed the first two of his nine symphonies as his hearing began to deteriorate, the Heroic period in which he composed his third through eighth symphonies and broke away from the traditional classical style, and the Late period in which he suffered his most severe hearing loss (Greenberg, 2013b).

\section{Copyrights}

Copyright for this article is retained by the author(s), with first publication rights granted to the journal.

This is an open-access article distributed under the terms and conditions of the Creative Commons Attribution license (http://creativecommons.org/licenses/by/3.0/). 